\title{
Comparative Studies on Surface Hydrophobicity of Streptococcal Strains of Groups A, B, C, D and G
}

\author{
By TORKEL WADSTRÖM, ${ }^{1}{ }^{*}+$ KARL-HERMAN SCHMIDT, ${ }^{2}$ \\ OTTO KÜHNEMUND, ${ }^{2}$ JIRI HAVLÍCEK ${ }^{3}$ AND WERNER KÖHLER ${ }^{2}$ \\ ${ }^{1}$ Department of Bacteriology and Epizootology, Swedish University of Agricultural Sciences, \\ College of Veterinary Sciences, Uppsala, Sweden \\ ${ }^{2}$ Academy of Sciences of GDR, Central Institute of Microbiology and Experimental Therapy, \\ Jena, GDR \\ ${ }^{3}$ Institute of Hygiene and Epidemiology, Prague, CSSR
}

(Received 14 March 1983; revised 6 October 1983)

Cell surface hydrophobicity of group A, B, C, D and G streptococcal strains has been studied and compared in a new test based on the fact that the degree of bacterial aggregation in ammonium sulphate depends on amphiphilic surface antigens. M-positive group A strains showing good growth in normal human blood aggregated in the standard salt aggregation test at very low concentrations of ammonium sulphate, while $\mathbf{M}$-negative strains, which were killed in normal human blood, usually aggregated at high salt concentrations. Agents such as $2 \mathrm{M}-\mathrm{KSCN}$, $2 \mathrm{M}$-guanidine. $\mathrm{HCl}$ or $2 \mathrm{M}$-urea decreased the aggregation of the $\mathrm{M}$-positive strains in the salt aggregation test while non ionic detergents such as Tween $20(1 \%, w / v)$ and ethylene glycol $(2 \mathrm{M})$ did not affect cell aggregation. Binding of fibrinogen and albumin resulted in a decrease of surface hydrophobicity of the group A M-positive strains. Group B strains possess a hydrophilic surface character and did not aggregate, while group $C$ and $G$ strains behaved in the salt aggregation test like M-negative strains of group A streptococci. Group D strains did not aggregate even at high ammonium salt concentrations. The results are discussed in relation to the influence of lipoteichoic acid and other surface antigens on strains of the various groups, and it is suggested that $M$ protein and possibly also other surface proteins contribute to the high surface hydrophobicity of group A strains.

\section{INTRODUCTION}

Recent studies of two matched pairs of $\mathrm{M}$-positive $\left(\mathrm{M}^{+}\right)$strains of Streptococcus pyogenes and $\mathbf{M}$-negative $\left(\mathbf{M}^{-}\right)$laboratory variants have indicated important differences in the physicochemical surface properties of such paired strains. $\mathbf{M}^{+}$strains were found to possess a more negative surface charge and to express extreme surface hydrophobic properties as compared with other bacterial species (Tylewska et al., 1979; Faris et al., 1981; Wadström et al., 1981). Protein A-positive Staphylococcus aureus show a high tendency towards hydrophobic interaction in the same test system, i.e. chromatography on octyl and phenyl Sepharose gels, as compared with protein A-negative variants (Wadström et al., 1981). Various methods have been developed in recent years to study the surface hydrophobicity of bacteria, including (1) two-phase partition chromatography (Magnusson et al., 1977); (2) hydrophobic interaction chromatography (Smyth et al., 1978); (3) the contact angle method (van Oss \& Gillman, 1972); and (4) measurement of

$†$ Present address: Department of Bacteriology and Epizootology, Biomedicum, PO Box 583, S-751 23 Uppsala, Sweden.

Abbreviations: GI, growth index; LTA, lipoteichoic acid; SAT, salt aggregation titre. 
binding of a hydrophobic probe, i.e. a low molecular weight substance such as $\left[{ }^{14} \mathrm{C}\right]$ dodecanoic acid (Kjelleberg et al., 1980), to the bacterial surface.

In this study, surface properties of streptococci are presented which have been obtained by a novel method based on the principle of 'salting out' of proteins with ammonium sulphate ('salting out principle'), developed for studies of surface properties of fimbriated and nonfimbriated Escherichia coli (Lindahl et al., 1981). This method is based on the concept that bacteria with a hydrophobic surface character aggregate at a relatively low concentration of ammonium sulphate and other salt solutions containing ions from the left side of the Hofmeister series (Hanstein, 1979). Preliminary experiments with fimbriated $\left(\mathrm{F}^{+}\right)$enterotoxigenic $E$. coli and negative $\left(\mathrm{F}^{-}\right)$variants clearly showed that the salting out principle was a promising new tool for quantifying differences in hydrophobicity between bacterial strains with various fimbrial antigens (Lindahl et al., 1981).

The aim of this investigation was to adopt a more systematic approach in order to study the surface properties of potentially pathogenic streptococci of groups A, B, C, D and G. For this purpose, standard strains of group A streptococci with different $M$ and $T$ antigen contents were first investigated. For comparative studies, strains of four other groups were also examined. Group B streptococci were included because they have been reported to possess a potential hydrophilic surface structure (Jennings et al., 1980). Group C and.G streptococci were selected since some are known to show differences in surface hydrophobicity, as revealed by partition experiments in polymer phase systems (Miörner et al., 1980). Group D streptococci were selected since they contain lipoteichoic acid (LTA) as group antigen.

\section{METHODS}

Bacterial strains. Streptococcal strains of groups A, B, C, G and D used in this study are listed in Table 1. Culture conditions and bacterial suspensions. Group A, B, C and G strains were grown in beef heart proteose broth for $12 \mathrm{~h}$ at $37^{\circ} \mathrm{C}$ in static cultures. Group D strains were grown in nutrient broth with $1 \%$ (w/v) glucose. All broth cultures were heat-killed at $60{ }^{\circ} \mathrm{C}$ for $30 \mathrm{~min}$. Daily repeated tests for one week of such suspensions gave reproducible results. Cultures were centrifuged $\left(3500 \mathrm{~g}, 15 \mathrm{~min}, 20^{\circ} \mathrm{C}\right)$ and washed twice with $0.01 \mathrm{M}$-sodium phosphate buffer, $\mathrm{pH} \mathrm{8.5}$, containing $10 \%(\mathrm{v} / \mathrm{v})$ ethylene glycol, then with $0.01 \mathrm{M}$-sodium phosphate, $\mathrm{pH} 7.3$ (standard phosphate buffer) to remove loosely bound surface components, such as medium constituents and extracellular proteins (Hjertén, 1981).

Bactericidal test. The survival of group A streptococci was tested in heparinized fresh human blood according to Sramek (1977). About 100 colony-forming units in $0.04 \mathrm{ml}$ culture broth were inoculated in $0.3 \mathrm{ml}$ human blood supplemented by $0.02 \mathrm{ml}$ normal rabbit serum and incubated for $3 \mathrm{~h}$ at $37^{\circ} \mathrm{C} ; 0.1 \mathrm{ml}$ of the blood cultures was then applied to sheep blood agar plates and incubated overnight. Survival was expressed by the growth index (GI) according to Lancefield (1957) and Stollerman et al. (1958).

$$
\mathrm{Gl}=\frac{\text { number of colony-forming units of } 0.1 \mathrm{ml} \text { of blood culture }}{\text { number of colony-forming units of the inoculum }} \times 100
$$

Strains with a $\dot{G I} \geq 30$ were designated as $\mathbf{M}^{+}$, the others $(\mathrm{GI}<30)$ as $\mathbf{M}^{-}$. Strains with a $\mathrm{GI} \geq 30$ possess $\mathrm{M}$ protein (Stollerman et al., 1958: Lancefield, 1959). The amount of M protein in strains with GI 1-30 cannot be unambiguously determined from their resistance to bactericidal effect of human blood (Lancefield, 1959), but it is generally accepted that some correlation exists between the GI of these strains and their M protein content.

Standard procedure for the salt aggregation tests. These tests were performed as described previously (Lindahl $e t$ al., 1981). A bacterial suspension ( $5 \mu \mathrm{l})$ containing approximately $10^{10}$ organisms $\mathrm{ml}^{-1}$ in standard phosphate buffer $\left(A_{600}^{0.1 \mathrm{~cm}} 0.9\right)$ was mixed with an equal volume of a salt solution on a glass slide. Serial twofold dilutions of an ammonium sulphate solution (4-0.008 $\mathrm{M}$ ) containing $0.01 \mathrm{M}$-sodium phosphate, $\mathrm{pH} 7.3$, were mixed $1: 1$ with the bacterial suspensions. The slides were tilted for about $1 \mathrm{~min}$ and aggregation was read against a dark background I min later. All standard procedures were carried out at $20^{\circ} \mathrm{C}$. Positive reactions were scored as follows: large white aggregates as +++ to ++ , small white aggregates as + , and no visible reaction as - . Standard reference strains RII, 1800 Teiko and 46/1 (see Fig. 1) were included on each separate occasion when investigating different parameters. The reciprocal of the lowest molarity of ammonium sulphate solution (final concentration after mixing with bacteria) giving a -++ or ++ reaction was scored as the numerical value of bacterial surface hydrophobicity (salt aggregation titre, SAT). Tests at different bacterial concentrations showed that $10^{9}-10^{10}$ organisms $\mathrm{ml}^{-1}$ gave the most reproducible results: higher bacterial concentrations gave a more rapid aggregation and less clear end-points. Reproducibility of aggregation results was confirmed in repeated tests with standard strains. Day-to-day variation was never greater than one dilution step. 
Table 1. Streptococcal strains used in the salt aggregation test

\begin{tabular}{|c|c|c|c|c|c|}
\hline \multicolumn{6}{|c|}{ Group $A$ streptococci } \\
\hline Strain* & Origin & Type & Strain* & Origin & Type \\
\hline $40 / 58^{a}$ & Prague & M1 & $1800 /$ Teiko $^{a}$ & Prague & T12 \\
\hline $103^{a}$ & Prague & M1 & $46 / 1^{c}$ & Copenhagen & $\mathrm{T} 12$ \\
\hline $96 / 50^{a}$ & Prague & $\mathrm{T} 1$ & $119^{a}$ & Prague & M13 \\
\hline SF130/Griffith ${ }^{b}$ & Rockefeller Univ. & $\mathrm{T} 1$ & $8 / 59^{a}$ & Prague & T13 \\
\hline $196^{a}$ & Prague & M2 & $195^{a}$ & Prague & M15 \\
\hline $30 / 58^{a}$ & Prague & $\mathrm{T} 2$ & $51 / 58^{a}$ & Prague & T15 \\
\hline $118^{a}$ & Prague & M4 & $107^{a}$ & Prague & M17 \\
\hline $42 / 58^{a}$ & Prague & $\mathrm{T} 4$ & $36 / 59^{a}$ & Prague & T17 \\
\hline $53^{c}$ & Copenhagen & M5 & $120^{a}$ & Prague & M19 \\
\hline $102^{a}$ & Copenhagen & M6 & $35 / 58^{a}$ & Prague & T19 \\
\hline$T 4^{\prime \prime}$ & Jena & M6 & $\mathrm{R} 53 / 2943^{d}$ & PHLS, London & M22 \\
\hline $7 / 55^{a}$ & Copenhagen & T6 & & & \\
\hline $104^{a}$ & Copenhagen & M8 & & & \\
\hline $28 / 50^{a}$ & Copenhagen & $\mathrm{T} 8$ & $121^{a}$ & Prague & M25 \\
\hline $180^{a}$ & Copenhagen & M9 & $14 / 55^{a}$ & Prague & $\mathrm{T} 25$ \\
\hline $192^{b}$ & Copenhagen & M9 & $108^{a}$ & Prague & M26 \\
\hline $33 / 59^{a}$ & Copenhagen & T9 & $109^{a}$ & Prague & M27 \\
\hline NY5 $^{c}$ & Copenhagen & T10; M12 & $38 / 58^{a}$ & Prague & $\mathrm{T} 27$ \\
\hline $1800^{a}$ & Prague & M12 & IRP $41^{b}$ & Rockefeller Univ. & Type 28 (Lit. \\
\hline $\mathbf{R I I}^{a}$ & Prague & M12 & & & Beachey) \\
\hline \multirow[t]{2}{*}{$33 / 58^{a}$} & Prague & $\mathrm{T} 12$ & $77 / 50^{a}$ & Prague & M28 \\
\hline & \multicolumn{4}{|c|}{ Group B streptococci } & \\
\hline Strain & Origin & Type & Strain & Origin & Type \\
\hline $090^{b}$ & Rockefeller Univ. & Ia & $6313^{a}$ & Prague & III \\
\hline $\mathrm{R}^{2} \mathbf{B B}^{\mathrm{b}}$ & Rockefeller Univ. & Ib & Compton $\mathrm{R}^{d}$ & PHLS, London & $\mathbf{R}$ \\
\hline A909b & Rockefeller Univ. & Ic & Compton $\mathrm{X}^{d}$ & PHLS, London & $\mathrm{X}$ \\
\hline \multirow[t]{2}{*}{$18 \mathrm{RS} 2^{b}$} & Rockefeller Univ. & II & & & \\
\hline & \multicolumn{4}{|c|}{ Group C streptococci } & \\
\hline Strain & Origin & & Strain & Origin & \\
\hline \multirow{9}{*}{$\begin{array}{l}\mathrm{C} 14^{e} \\
\mathrm{C} 42^{e} \\
\mathrm{~F} 49^{r}\end{array}$} & Lund & & $78 \mathrm{~A}^{f}$ & Iowa State Univ. & \\
\hline & Lund & & $\mathbf{R} 8^{f}$ & Iowa State Univ. & \\
\hline & Iowa State Univ. & & $78 \mathrm{~B}^{f}$ & Iowa State Univ. & \\
\hline & \multicolumn{4}{|c|}{ Group D streptococci } & \\
\hline & \multicolumn{2}{|c|}{$\begin{array}{l}\text { Kiel } 3^{d} \\
S . \text { faecalis }\end{array}$} & $\begin{array}{l}\text { S. } f a \\
\text { S. } b o\end{array}$ & $\begin{array}{l}\text { ecium } \\
\text { vis }^{d}\end{array}$ & \\
\hline & \multicolumn{4}{|c|}{ Group G streptococci } & \\
\hline & \multirow{3}{*}{\multicolumn{2}{|c|}{$\begin{array}{l}\text { Strain } 20488^{h} \\
\text { Strain } 100182^{d} \\
\text { Strain } 100184^{d}\end{array}$}} & \multirow{3}{*}{\multicolumn{2}{|c|}{$\begin{array}{l}\text { Strain } 100185^{d} \\
\text { Strain G24e } \\
\text { Strain G28 }\end{array}$}} & \\
\hline & & & & & \\
\hline & & & & & \\
\hline
\end{tabular}

* Sources are indicated by superscript letters: $a$, Institute of Hygiene and Epidemiology, Prague, CSSR; $b$, Rockefeller University, New York, USA; $c$, Statens Serum Institut, Copenhagen, Denmark; $d$, Public Health Laboratory Service (PHLS), London, UK; e, Department of Medical Microbiology, University of Lund, Sweden; $f$, Veterinary Medical Research Institute, State University, Ames, lowa, USA; g, Isolate (Lab. no. 242 RK) obtained from F. Fehrenbach, Robert Koch Institute, West Berlin; $h$, Central Institute of Microbiology and Experimental Therapy, Jena, GDR.

The influence of different ions, $\mathrm{pH}$ and temperature was investigated by variation of the standard test conditions.

Trypsin and pepsin treatment. Cell suspensions $(200 \mu \mathrm{l})$ of group A, C, D and G strains were incubated after addition of $20 \mu \mathrm{l}$ trypsin $\left(1 \mathrm{mg} \mathrm{ml}{ }^{-1}\right.$ in $0.01 \mathrm{M}$-sodium phosphate buffer, $\left.\mathrm{pH} 7.3\right)$ or $20 \mu 1$ pepsin $\left(1 \mathrm{mg} \mathrm{ml}^{-1}\right.$ in $0.067 \mathrm{M}$-sodium phosphate buffer, $\mathrm{pH} 5.8$ ) at $37^{\circ} \mathrm{C}$ for $60 \mathrm{~min}$ (Beachey et al., 1980). The cells were then washed twice with the standard phosphate buffer.

Treatment of cell suspensions with human albumin, fibrinogen, dextran and homologous rabbit antistreptococcal antiserum. Suspensions $(200 \mu \mathrm{l})$ of group A streptococci were incubated for $1 \mathrm{~h}$ at $37^{\circ} \mathrm{C}$ with $1 \mathrm{ml}$ of the 
appropriate protein solutions ( $1 \mathrm{mg} \mathrm{ml} \mathrm{m}^{-1}$ in standard phosphate buffer) or $1 \mathrm{ml}$ of a $1: 10$ antiserum dilution, and then washed as described above. For dextran treatment, $150 \mu$ l of streptococcal suspensions were mixed with $50 \mu l$ of a $10 \%(w / v)$ dextran solution. Antisera against heat-killed $\left(60^{\circ} \mathrm{C}, 1 \mathrm{~h}\right)$ streptococcal cells were raised in rabbits according to Lancefield (1938).

Chemicals. Trypsin (twice crystallized), pepsin (twice crystallized), Tween 20 and sodium deoxycholate were purchased from Merck. Human fibrinogen and human serum albumin were obtained from Kabi, Stockholm, Sweden. Dextran was purchased from Pharmacia. Guanidine. HCl was obtained from Serva, Heidelberg, FRG. All other chemicals were obtained from VEB Jenapharm-Laborchemie, Apolda, GDR, and were of analytical grade.

\section{RESULTS}

\section{Behaviour of group $A$ strains in the salt aggregation test}

The results of the salt aggregation of 39 group A streptococcal strains are shown in Fig. 1. The majority of the strains with a GI $>30$ clearly show a higher tendency to aggregate in the salting out test than strains with a lower GI. Some of the strains, most of them with higher GI, exhibited autoaggregation in the standard phosphate buffer. Digestion with trypsin or mild treatment with pepsin (Beachey et al., 1977) was used to remove M protein and other cell wall components from the surface of group A streptococci. As expected, after trypsin treatment the high GI index strains aggregated only at high ammonium sulphate concentrations while the low GI strains remained almost unaffected (Fig.2,A). Mild pepsin digestion also reduced surface hydrophobicity, but to a lesser extent than trypsin digestion (not illustrated).

\section{Influence of $\mathrm{pH}$, temperature, ions and several compounds on salt aggregation}

Comparative tests at acidic and alkaline $\mathrm{pH}$ with selected strains showed that a pH below 7 enhanced aggregation (not illustrated). Standard tests at various temperatures $\left(4,20\right.$ and $\left.37^{\circ} \mathrm{C}\right)$ revealed differences in the numerical score for a $++1+++$ reaction only for the type $\mathrm{M} 12$ strain 1800 (Fig. 2, C). Chaotropic agents known to dissolve intrinsic membrane proteins ('salting in') inhibited the aggregation of the tested strains. Aggregation of strain 40/58 (SAT =

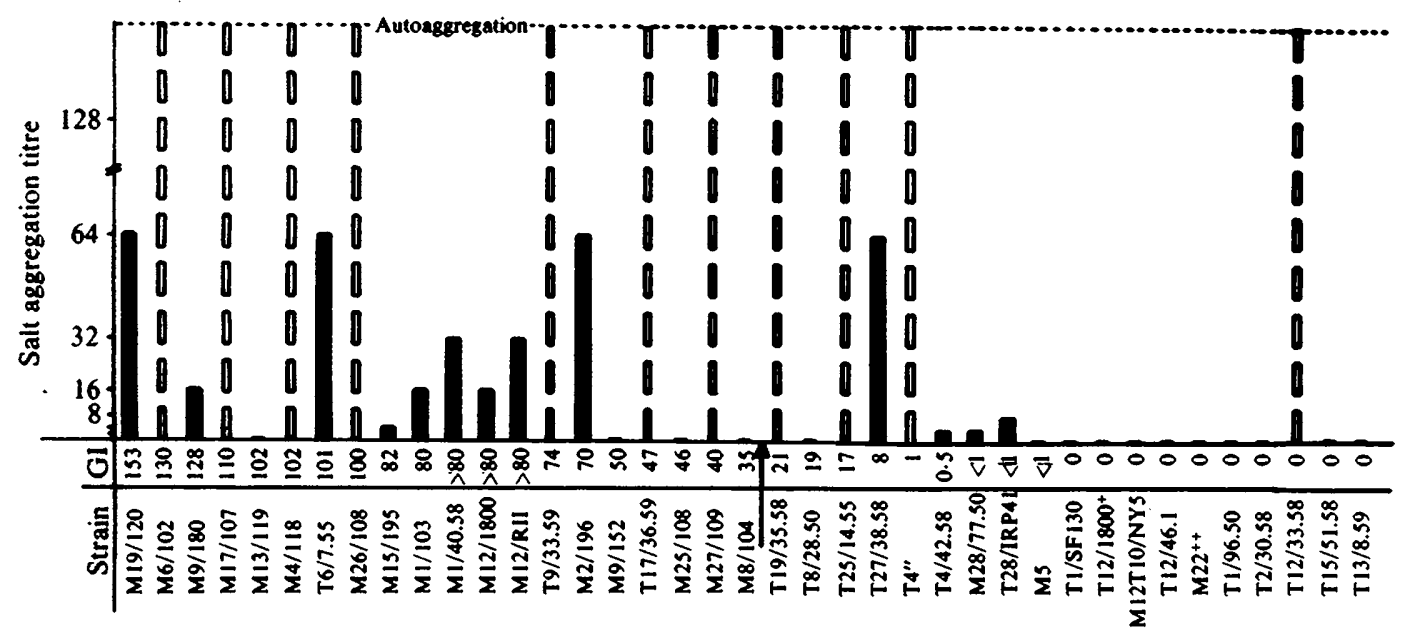

Fig. 1. Salt aggregation test of different strains of group A streptococci (all $S$. pyogenes). The salt aggregation titre is the reciprocal of the lowest ammonium sulphate concentration (in mol $1^{-1}$ ) which gave an aggregation scored as ++ . GI, growth index. Designation of strains: M19/120 means type M19, strain no. 120, etc. T4", an isolate obtained from Professor F. Fehrenbach, West Berlin; $T 12 / 1800^{++}$, strain 'Teiko', an $\mathrm{M}^{-}$strain obtained from strain $\mathrm{M} 12 / 1800$ after about 50 blood plate passages; $M 22^{++}$, strain R53/2943. The arrow between GI 35 and 21 represents the limit between $\mathbf{M}^{+}$ $(G I>30)$ and $M^{-}(G I<30)$ strains. $\square$, Salt aggregation titre; $\square \square$, strains which autoaggregate (autoagglutinate), even in standard phosphate buffer. 


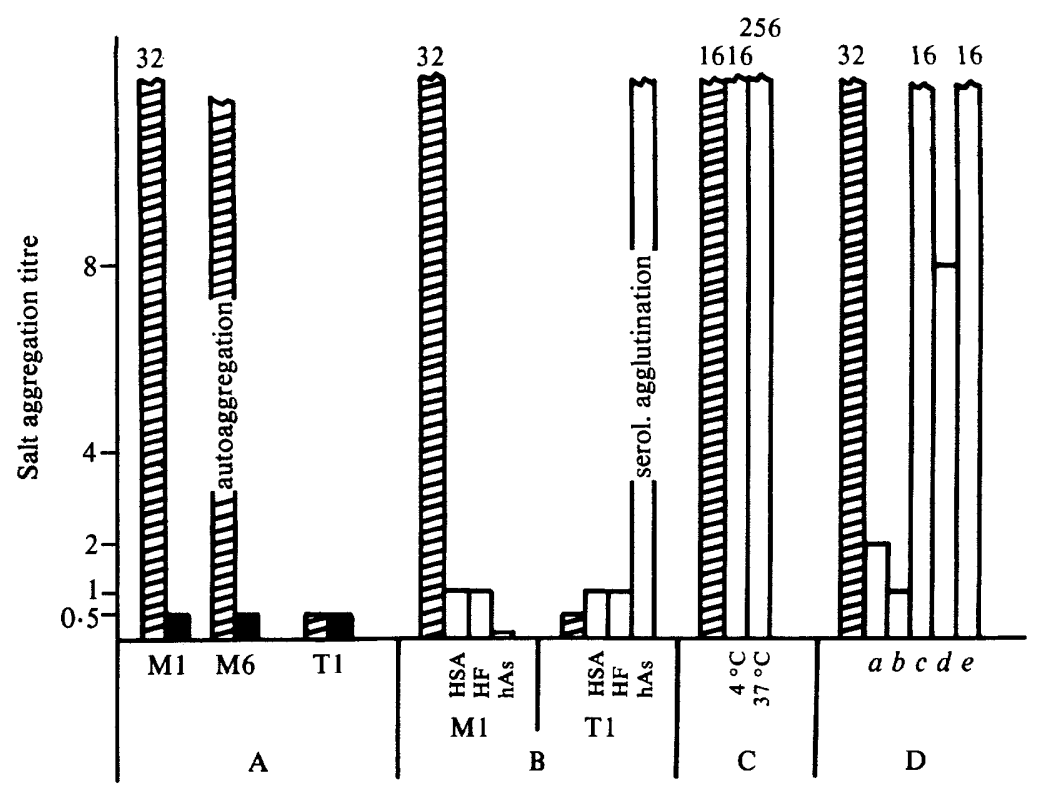

Fig. 2. Influence of various agents and parameters on the salt aggregation titre of group A streptococci. A. Trypsinization:E, Untreated strains, $20^{\circ} \mathrm{C}$; , trypsinized strains. M1, type $\mathrm{M} 1$ streptococcus strain 40/58; M6, type M6 strain 102; T1, type T1 strain SF130/Griffith.

B. Coating of group A streptococci type M1 strain 40/58 (M1) and type T1 strain SF130/Griffith (T1) with different serum components. $\square$, untreated strains; $\square$, coated strains. HSA, human serum albumin; HF, human fibrinogen; hAs, homologous antistreptococcal antiserum from rabbits.

C. Influence of temperature on the salt aggregation titre of the group A streptococcus type M12 strain 1800. $\square, 20^{\circ} \mathrm{C} ; \square$, changed temperature.

D. Influence of various agents on the salt aggregation titre of group A streptococcus type M1 strain 40/58. $\boxminus$, untreated bacteria; $\square$, salt aggregation titre in presence of various agents. The agents were $a$, $2 \mathrm{M}-\mathrm{KSCN} ; b, 2$ M-urea; $c, 2 \cdot 5 \%$ dextran T40;, $1 \%$ Tween $20 ; e, 2$ M-ethylene glycol.

32) was inhibited to SAT $<2$ by 2 M-KSCN (Fig. 2, D) and to SAT $<4$ by 1 M-guanidine. $\mathrm{HCl}$. Urea $(2 \mathrm{M})$ also inhibited salt aggregation with ammonium sulphate. Only slight differences were detectable in the aggregation behaviour of type M1 strain 40/58 (GI >80), type M6 strain $102(\mathrm{GI}=130)$ and type M12 strain $1800(\mathrm{GI}=80)$ streptococci with dilution series of ammonium acetate, ammonium sulphate and ammonium chloride, representing, in that order, a decreasing salting out potency in the Hofmeister series. Treatment of bacterial suspensions with a dilution series of KSCN caused no aggregation. The nonionic detergents Tween 20 (Fig. 2, D) and Triton $\mathrm{X}-100$, and a weak ionic detergent (sodium deoxycholate), used to solubilize hydrophobic membrane proteins (Helenius \& Simons, 1975), reduced the SAT value slightly. Ethylene glycol $(2 \mathrm{M})$ did not influence the bacterial aggregation of the tested strains in $0.06 \mathrm{M}$ salt solutions (Fig. 2, D).

Various blocking experiments were performed with human serum albumin, human fibrinogen and homologous rabbit antiserum, which are known to bind to structures such as LTA, M and T proteins and other streptococcal surface antigens (Simpson et al., 1980; Kantor, 1965; Schmidt \& Köhler, 1981; A. Wicken, personal communication). Treatment of group A strains having a high GI with human serum albumin or fibrinogen caused a fivefold decrease in SAT although the inhibition was never complete (Fig. 2, B; strain 40/58). Conversely, after coating type T1 strains with low GI (e.g. SF130/Griffith, GI =0), a slight increase in SAT was found (Fig. 2, B). Thus, strains which behaved differently before treatment were aggregated at the same SAT after treatment.

In the case of the group A type M12 strain 1800, after coating with fibrinogen a strong salt aggregation was observed at SAT $\leq 1$. The aggregation was weak at SAT 2 and 4 and 
became strong again at SAT $\geq 8$, perhaps because of a fibrinogen streptococcal agglutination (Tillet \& Garner, 1934).

The use of homologous rabbit antiserum for coating gave no clear results, probably because of serological agglutination. The presence of $2.5 \%$ dextran only slightly influenced the salt aggregation (Fig. 2, D). Since dextran binds to surface-located LTAs (A. Wicken, personal communication) the observation suggests that this amphiphile is not the main surface component which determines streptococcal hydrophobicity.

\section{Comparative tests with streptococcal strains of groups $B, C, D$ and $G$}

Group B streptococcal strains of different serotypes (Type Ia, Ib, Ic, II and III) produce carbohydrate capsules (Jennings et al., 1980). Salt aggregation tests confirmed their hydrophilic surface character. None of the strains showed a SAT higher than 0.5 . Group $C$ and $G$ strains behaved in a similar way to $\mathrm{M}^{-}$group A streptococci, and aggregated at SAT 0.5 or 1 . Group D streptococcal strains did not aggregate even at high salt concentrations.

\section{DISCUSSION}

Studies of two selected matched pairs of $\mathbf{M}^{+}$and $\mathbf{M}^{-}$group A streptococci by hydrophobic interaction chromatography showed that the $\mathbf{M}^{+}$strains had a much higher relative surface hydrophobicity than the $\mathbf{M}^{-}$strains (Tylewska et al., 1979). These observations stimulated further investigations of the physicochemical surface properties of standard streptococcal strains of various $M$ types and serogroups other than group $A$. It is generally accepted that a high growth index in standard bactericidal tests correlates to the amount of $\mathbf{M}$ protein present on group A streptococci (Lancefield, 1959; Stollerman et al., 1958). The correlation between the $M$ protein content (as determined in the bactericidal test) and the salting out behaviour of streptococcal strains demonstrated in this study shows that an increased $\mathbf{M}$ protein content is associated with increased hydrophobicity of the streptococcal surface. Practically all group A strains with a GI $\leq 1\left(\mathrm{M}^{-}\right)$showed SAT values of 4 or less. Group B, C, D and G strains also showed a low tendency to aggregate.

Among the group A streptococci tested were some $\mathbf{M}^{-}$strains which showed autoaggregation, and a few $\mathrm{M}^{+}$strains $(\mathrm{GI}>30)$ which were aggregated only by high ammonium sulphate concentrations (SAT <2), showing that hydrophobicity of the group A streptococci is not solely determined by $M$ protein. Indeed, experiments with group $A$ type $M 1$ and type $M 12$ streptococcal extracts have shown that $M$ proteins in solution do not behave in a very hydrophobic manner (Kühnemund et al., 1982). Thus, other factors which influence the surface hydrophobicity may accompany the $M$ proteins on the cell surface.

The fact that cell aggregation was diminished by chaotropic ions or nonionic detergents in the standard salting out assay strongly suggests that hydrophobic interactions are the main forces involved, but that other forces such as electrostatic interactions must be considered at lower salt concentrations, especially in the case of autoaggregating strains. Systematic studies on fimbriated $E$. coli with different salts and including chaotropic agents have clearly shown a correlation between bacterial cell surface hydrophobicity and amount of amphiphilic cell surface structures such as fimbriae (Lindahl et al., 1981).

Incubation of streptococci with albumin and fibrinogen diminished the SAT value. Studies of the binding of various serum proteins such as albumin (Myhre \& Kronvall, 1980; Simpson et al., 1980), $\beta_{2}$-microglobulin (Björck et al., 1981), haptoglobin (Köhler \& Prokop, 1978), fibrinogen (Kronvall et al., 1979a; Schmidt \& Köhler, 1981), and immunoglobulins (Kronvall et al., 1979b) to streptococcal surface components indicate a complex surface mosaic structure of these cells. LTA may be an important receptor for surface-bound albumin (Simpson et al., 1980) which may sterically hide the hydrophobic proteins on the cell surface. Similar steric blocking may also occur after adsorption of fibrinogen or immunoglobulin on the cell surface. Thus, the surface properties of group A sterptococci in vivo may be dominated by the effect of coating with other proteins.

Studies with group B, C, D and G streptococci were also performed because of the different 
cell surface properties in these groups. Group B streptococci with a polysaccharide capsule were shown to have a hydrophilic surface character. Recent studies of a capsulated Staph. aureus strain (Smith diffuse strain) and its negative variant (Smith compact strain) also show that the presence of hydrophilic surface carbohydrates can occlude suface hydrophobic properties attributed to protein A and other surface antigens (Jonsson \& Wadström, 1983). The group C and $G$ streptococci tested showed a similar salting out behaviour to that of the low GI group $A$ strains.

The behaviour of the group D streptococci which possess surface LTA as the group antigen did not indicate surface exposure of the lipid part of the amphiphilic LTA molecule. These results indicate that LTA is probably synthesized and located in the group D cell envelope, and accordingly not exposed on the surface of the cell wall as proposed in the classical model of LTA in lactic acid-producing streptococci and lactobacilli (Wicken \& Knox, 1980), because such strains expressed a hydrophilic surface character in our test system.

The generous supply of strains from various laboratories is gratefully acknowledged. Support from the Royal Swedish Academy of Sciences and the Academy of Sciences of the GDR for visiting scientists is gratefully acknowledged. Part of this study was also supported by a grant from the Swedish Board for Technical Development to T.W.

\section{REFERENCES}

Beachey, E. H., Simpson, W. A. \& Ofek, I. (1980). Interaction of surface polymers of Streptococcus pyogenes with animal cells. In Microbial Adhesion to Surfaces, pp. 389-405. Edited by R. C. W. Berkeley, J. M. Lynch, J. Melling, P. R. Rutter \& B. Vincent. Chichester: Ellis Horwood.

Beachey, E. H., Stollerman, G. H., Chiang, E. Y., Chiang, T. M., Seyer, J. M. \& Kang, A. H. (1977). Purification and properties of $\mathbf{M}$ protein extracted from group A streptococci with pepsin: covalent structure of the amino terminal region of type $24 \mathrm{M}$ antigen. Journal of Experimental Medicine 145, 14691483.

BJöRCK, L., TYlewSKA, S. K., WADSTRÖM, T. \& KRONVALL, G. (1981). $\beta_{2}$-microglobulin is bound to streptococcal $\mathbf{M}$ protein. Scandinavian Journal of Immunology 13, 391-394.

i'ARIS, A., Wadström, T. \& Freer, J. (1981). Hydrophobic adsorptive and hemagglutinating properties of Escherichia coli possessing cononization factor antigens (CFA/I or CFA/II), type 1 pili, or other pili. Current Microbiology 5, 67-72.

Hanstein, W. G. (1979). Chaotropic ions and their interactions with proteins. Journal of Solid Phase Biochemistry 4, 189-195.

Helenius, A. \& Simons, K. (1975). Solubilization of membranes by detergents. Biochimica et biophysica acta 415, 29-79.

HJertén, S. (1981). Hydrophobic interaction chromatography of proteins, nucleic acids, viruses and cells on non-charged amphiphilic gels. Methods of Biochemical Analysis 27, 89-108.

Jennings, H. J., Rosell, K. G. \& Kasper, D. L. (1980). Structure of the native polysaccharide antigen of type la group B streptococcus. Proceedings of the National Academy of Sciences of the United States of America 77, 2931-2935.

Jonsson, P. \& WadSTRÖM, T. (1983). High surface hydrophobicity of Staphylococcus aureus as revealed by hydrophobic interaction chromatography. Current Microbiology 8, 347-353.
KANTOR, F. S. (1965). Fibrinogen precipitation by streptococcal $M$ protein. I. Identity of the reactants and stoichiometry of the reaction. Journal of Experimental Medicine 121, 849-859.

KJelleberG, S., Lagerkrantz, C. \& Larsson, T. (1980). Quantitative analysis of bacterial hydrophobicity studied by the binding of dodecanoic acid. FEMS Microbiology Letters 7, 41-44.

KöHler, W. \& ProKoP, O. (1978). Relationship between haptoglobin and Streptococcus pyogenes T4 antigens. Nature, London 271, 373-375.

Kronvall, G., Schönbeck, C. H. \& Myhre, E. $(1979 a)$. Fibrinogen binding structures in $\beta$-haemolytic streptococci of groups A, C, and G. Acta pathologica et microbiologica scandinavica B87, 303-310.

Kronvall, G., Simmons, A. \& MYhre, E. (1979b). Specific adsorption of human albumin, immunoglobulin $A$ and immunoglobulin $G$ with selected strains of group $\mathrm{A}$ and $\mathrm{G}$ streptococci. Infection and Immunity 25, 1-10.

KÜHNEMUND, O., HAVliCEK, J., SChMidT, K. H., WADSTRÖM, T. \& KöHLER, W. (1982). Relationship of $\mathbf{M}$ protein to hydrophobic properties of streptococcal cells. In Basic Concepts of Streptococci and Streptococcal Diseases, p. 82. Edited by S. E. Holm \& P. Christensen. Chertsey: Reedbooks.

LANCEFIELD, R. C. (1938). A microprecipitin technique for classifying haemolytic streptococci, and improved methods for producing antisera. Proceedings of the Society for Experimental Biology and Medicine 38, 473-478.

LANCEFIELD, R. C. (1957). Differentiation of group A streptococci with a common $R$ antigen into three serological types with special reference to the bactericidal test. Journal of Experimental Medicine 106, p. 525.

LANCEFIELD, R. C. (1959). Persistence of type-specific antibodies in man following infection with group $A$ streptococci. Journal of Experimental Medicine 110, 271-278.

Lindahl, M., FARIS, A., WADSTRöM, T. \& HJERTÉN, S. 
(1981). A new test based on 'salting out' to measure relative surface hydrophobicity of bacterial cells. Biochimica et biophysica acta 677, 471-476.

Magnusson, K. E., Stendahl, O., Tagesson, C., EDEbo, L. \& Johansson, G. (1977). The tendency of smooth and rough Salmonella typhimurium bacteria and lipopolysaccharide to hydrophobic and ionic interaction as studied in aqueous polymer two phase systems. Acta pathologica et micrabiologica scandinavica B85, 212-218.

Miörner, H., Myhre, E., Buörck, L. \& Kronyall, G. (1980). Effect of specific binding of human albumin, fibrinogen and immunoglobulin $G$ on surface characteristics of bacterial strains as revealed by partition experiments in polymer two phase systems. Infection and Immunity 29, 879-885.

MYHRE, E. B. \& KRONVALL, G. (1980). Demonstration of specific binding sites for human serum albumin in group $C$ and $G$ streptococci. Infection and Immunity 27, 6-14.

van Oss, C. \& Gillman, C. F. (1972). Phagocytosis as a surface phenomenon. 1. Contact angles and phagocytosis of nonopsonized bacteria. Journal of the Reticuloendothelial Society 12, 283-292.

SCHMIDT, K. H. \& KÖHLR, W. (1981). Interaction of streptococcal cell wall components with fibrinogen. I. Communication: adsorption of fibrinogen by immobilized T proteins of Streptococcus pyogenes. Immunobiology 158, 330-337.

Simpson, W. A., OfEK, I. \& BeAchey, E. H. (1980). Binding of Streptococcus lipoteichoic acid to the fatty acid binding sites on serum albumin. Journal of Biological Chemistry 255, 6092-6097.

SMYth, C. J., JonsSon, P., OlsSon, E., SOdDerlind, O., Rosengren, J., HJertén, S. \& WaDSTröm, T.
(1978). Differences in hydrophobic surface characteristics of porcine enteropathogenic Escherichia coli with or without $\mathrm{K} 88$ antigen as revealed by hydrophobic interaction chromatography. Infection and Immunity 22, 462-472.

SRAMEK, J. (1977). Bactericidal test for measurement of type specific (anti-M) antibodies to group A streptococci. Standard Technique of WHO Collaboration Center for Reference and Research on Streptococci, pp. 1-4. Prague: Institute of Hygiene \& Epidemiology.

Stollerman, G. H., Kantor, F. S. \& Gordon, D. B. (1958). Accessory plasma factors involved in the bactericidal test for type specific antibody to group A streptococci. I. Atypical behaviour of some human and rabbit bloods. Journal of Experimental Medicine 108, 475-491.

Tillett, W. S. \& GARNER, R. L. (1934). The agglutination of hemolytic streptococci by plasma and fibrinogen. Bulletin of the Johns Hopkins Hospital 54, 145-156.

TYleWSKA, S. K., HJERTÉN, S. \& WADSTRÖM, T. (1979). Contribution of the hydrophobic surface properties of Streptococcus pyogenes. FEMS Microbiology Letters 6, 249-253.

WADSTRÖM, T., HJertén, S., JonsSON, P. \& TYLEWSKA, S. K. (1981). Hydrophobic surface properties of Staphylococcus aureus, Staphylococcus saprophyticus and Streptococcus pyogenes: a comparative study. In Staphylococci and Staphylococcal Infections, pp. 441-447. Edited by J. Jeljaszewicz. Stuttgart: Gustav Fischer.

WICKEN, A. J. \& KNoX, K. W. (1980). Bacterial cell surface amphiphiles. Biochimica et biophysica acta 604, 1-26. 